\title{
Penafsiran Hukum dalam Menentukan Unsur-Unsur Kelalaian Malpraktek Medik (Medical Malpractice)
}

\author{
Widodo Tresno Novianto \\ Fakultas Hukum Universitas Sebelas Maret \\ Email : novianto@consultant.com
}

\begin{abstract}
Struggle interpretation of the law to determine the elements of errors / omissions in Medical Malpractice often encountered in the process of resolving a medical action performed by a doctor with allegations of errors / omissions / negligence and irregularities health care procedures / professional errors / omissions professionals. Legal battle to determine the elements of negligence in Medical Malpractice is situated on the difference between the interpretation and application of ordinary criminal offenses set out in the Criminal Code and the crime of medical. Where ordinary crime that primarily focuses on the factor of "consequences" of a criminal act, whereas in criminal acts medical visits is not the result but the factor of "the cause", so although fatal but if there is no element of negligence or fault, then the doctor can not be held. From the point of criminal law (Criminal Code) an assessment of its legal action against the medical culpa lata should start from the death / injury, and then assess the medical in observing behavior was to blame or not to blame. This indicates the presence of a paradigm shift is from "due to" the act of giving medication into an act eliminating symptoms after performing the act, but an attitude of "inner culpoos" is formed from the consequences of doing an act, and not after the act was committed.
\end{abstract}

Keywords : Struggle, Interpretation, Negligence, Medical

\begin{abstract}
Abstrak
Pergulatan penafsiran hukum untuk menentukan unsur- unsur kesalahan / kelalaian dalam Malpraktek Medik sering dijumpai dalam proses penyelesaian suatu tindakan medik yang dilakukan oleh dokter dengan dugaan terjadinya kesalahan/ kealpaan / kelalaian dan penyimpangan prosedur pelayanan kesehatan / kesalahan profesional / kelalaian profesional. Pergulatan hukum untuk menentukan unsur-unsur kelalaian dalam Malpraktik Medik (Medical Malpractice) adalah terletak pada adanya perbedaan penafsiran dan penerapan antara tindak pidana biasa yang diatur dalam KUHP dan tindak pidana medis . Dimana tindak pidana biasa yang terutama berfokus pada faktor " akibatnya " dari suatu peristiwa pidana , sedangkan dalam tindak pidana medis yang dilihat bukan akibatnya tetapi faktor " penyebabnya ", sehingga meskipun berakibat fatal tetapi jika tidak ada unsur kelalaian atau kesalahan, maka dokter tidak dapat dipersalahkan. Dari sudut hukum pidana ( KUHP) penilaian sifat melawan hukumnya perbuatan dalam culpa lata medis harus dimulai dari akibat kematian / luka , baru kemudian menilai pada tingkah laku medis dalam mengobservasi yang patut disalahkan atau tidak disalahkan. Hal ini menunjukkan dengan adanya pergeseran paradigma yaitu dari "akibat" perbuatan memberikan pengobatan menjadi perbuatan menghilangkan gejala setelah melakukan
\end{abstract}


perbuatan, padahal sikap " batin culpoos " terbentuk dari akibat dilakukannya suatu perbuatan , dan bukan sesudahnya perbuatan itu dilakukan.

\section{Kata kunci : Pergulatan, penafsiran, kelalaian, medik}

\section{A. Pendahuluan}

Keselamatan pasien merupakan suatu hal yang utama bagi dokter dalam menjalankan tugasnya (aegroti salus lex suprema), karena hal ini sudah merupakan suatu kewajiban dokter dalam mengobati orang sakit, sesuai dengan Sumpah Hippocrates yang dipakai sebagai pedoman dasar bagi dokter sampai saat ini. Disamping itu adalah hak setiap orang untuk mendapatkan pelayanan kesehatannya, karena itu dalam tatanan masyarakat dimanapun, sudah merupakan kewajiban masyarakat melalui profesi kedokteran untuk mengobati orang sakit, dan mengobati orang sakit adalah “ Fardhu Kifayah “ (Azwar , 2002 : 2 )

Pada dasarnya praktik dokter merupakan pemberian bantuan secara individual oleh dokter kepada pasien berupa pelayanan medis. Apabila seseorang datang kepada dokter untuk memanfaatkan pelayanan medis yang tersedia maka terjadi hubungan hukum antara dokter dan pasien yang disebut tranksaksi terapeutis. Hubungan hukum yang tidak menjanjikan sesuatu kesembuhan atau kematian semacam ini disebut inspanningsverbintenis, yang berbeda dengan hubungan hukum yang biasa berlaku dalam perjanjian pada umumnya yang menjanjikan suatu hasil yang pasti (risikoverbentenis / resultaatsverbentenis).

Dalam hubungan hukum yang demikian ini mensyaratkan adanya hak dan kewajiban antara dokter dan pasien, dan juga melahirkan / membentuk pertanggung jawab hukum masing-masing. Pihak dokter maka prestasi berbuat sesuatu atau tidak berbuat sesuatuin casu tidak berbuat salah atau keliru dalam perlakuan medis yang semata-mata ditujukan bagi kepentingan kesehatan pasien adalah kewajiban hukum yang mendasar dalam perjanjian dokter dan pasien / kontrak terapeutik (Pasal 39 UU Nomor 29 / 2004 Praktik Kedokteran).

Kedudukan dokter selaku professional di bidang medis mempunyai peran aktif dalam pelayanan medis dan pasien sebagai penerima pelayanan medis mempunyai penilaian terhadap penampilan dan mutu pelayanan medis yang diterimanya. Hal ini disebabkan dokter bukan hanya melaksanakan pekerjaan melayani atau memberi pertolongan semata-mata tetapi juga melaksanakan profesi yang terikat pada kode etik profesi. Kedudukan pasien yang semula hanya sebagai pihak bergantung kepada dokter dalam menentukan cara penyembuhan (terapi), kini berubah menjadi pihak yang sederajat dengan dokter. Dokter tidak boleh lagi mengabaikan pertimbangan pendapat pasien dalam memilih cara pengobatan, termasuk untuk menentukan perlunya tindakan operasi atau tidak. Disamping itu , kenyataan menunjukkan bahwa kemajuan teknologi dan semakin kritisnya masyarakat terhadap pelayanan medis yang diterimanya menyebabkan semakin mengecilnya kesenjangan pengetahuan antara pasien dan dokter serta makin terbukanya penilaian dan kritik.

Kedudukan pasien yang semula hanya sebagai pihak bergantung kepada dokter dalam menentukan cara penyembuhan (terapi), kini berubah menjadi pihak yang sederajat dengan dokter. Dokter tidak boleh lagi mengabaikan pertimbangan pendapat pasien dalam memilih cara pengobatan, termasuk untuk 
menentukan perlunya tindakan operasi atau tidak. Meskipun demikian pelaksanaan kewajiban hukum dokter selalu dibayangi adanya resiko, baik bagi pasien maupun dokter. Bagi pasien maka pelayanan dokter dapat membawa / menimbulkan kerugian kesehatan atau bahkan nyawanya, sedangkan bagi dokter pertanggungjawaban dapat berupa sanksi mulai dari yang ringan sampai berat, yang bersifat moral kemasyarakatan sampai pada aspek hukum. Akan tetapi disisi lain tidak dipenuhinya kewajiban pasien dalam hubungan ini ( misalnya tidak patuh pada petunjuk / nasihat dokter/ tidak memberikan keterangan yg tidak benar tentang penyakitnya sehingga mempengaruhi diagnosis maupun terapi dokter dalam perlakuan medis.

Walaupun pada dasarnya hubungan pasien - dokter adalah hubungan hukum perdata, namun tidak menutup kemungkinan pelayanan medis dokter diluar standar profesi dapat dikategorikan / masuk dalam ranah hukum pidana dan hukum administratif . Memang dalam praktik sedikit sulit untuk membedakan antara kerugian akibat adanya perbuatan melawan hukum dengan kerugian akibat wanprestasi dalam malpraktik kedokteran. Oleh karena itu dalam peristiwa malpraktik kedokteran apakah adanya / timbulnya kerugian itu disebabkan akibat wanprestasi dokter atau perbuatan melawan hukum, akan sangat tergantung pada alasan gugatan / tuntutan yang diajukan oleh pasien. Hal ini disebabkan karena pada intinya akibat yang ditimbulkan akan sampai pada satu titik yaitu adanya penyimpangan pelayanan medis yang dilakukan oleh dokter (wan prestasi)

Termasuk dalam wanprestasi apabila dokter tidak melaksanakan kewajiban perlakuan medis dengan sebaik-baiknya dan secara maksimal ( misalnya karena pasien tidak punya cukup uang membiayai pengobatannya, melaksanakan kewajiban yang tidak sesuai / diluar standar profesi dan standar prosedur. Sedangkan perbuatan melawan hukum dalam praktik kedokteran terjadi apabila dalam perlakuan medis terdapat kesalahan dengan menimbulkan akibat kerugian, maka pasien dapat menuntut berdasarkan perbuatan melawan hukum seperti yang diatur dalam Pasal 1365 BW yang secara implisit dirumuskan " tiap perbuatan melanggar hukum yang membawa kerugian kepada orang lain, mewajibkan orang yang karena salahnyamenimbulkan kerugian itu untuk mengganti kerugian tersebut ". Rumusan kata " karena salahnya " dalam ketentuan Pasal 1365 KUHPerdata dapat berbentuk kesengajaan (dolus) ataupun berupa kelalaian (culpa) yang dilakukan dokter dalam perlakuan medis yang salah terhadap pasien. Ada syarat yang harus dipenuhi untuk menuntut kerugian adanya perbuatan melawan hukum dalam Pasal 1365 KUHPerdata antara lain sebagai berikut : 1) Adanya perbuatan ( daad ) yang termasuk kualifikasi perbuatan melawan hukum; 2) Adanya kesalahan ( dolus dan/ atau culpa ); 3) Adanya kerugian ( schade ). Perlakuan yang tidak benar menjadi suatu pelanggaran perjanjian (wanprestasi) dan atau perbuatan melawan hukum(onrechtmatige daad).Untuk seorang dokter baru dapat dikatakan melakukan perbuatan melawan hukum sesuai dengan ketentuan Pasal 1365 KUHPerdata harus terpenuhinya syarat-syarat atau unsur-unsur antara lain : (a) Perbuatan tersebut merupakan perbuatan melawan hukum ( onrechtmatige daad),(b) harus ada kesalahan ,(c) harus ada kerugian yang ditimbulkan, (d) adanya hubungan kausal antara perbuatan dan kerugian. 
Secara harfiah praktik kedokteran adalah suatu kegiatan yang mengandung berbagai wujud konkrit tingkah laku. Perbuatan dalam perlakuan medis dokter dapat berupa perbuatan aktif dan dapat pula berupa perbuatan pasif. Perbuatan aktif, artinya perbuatan yang memerlukan gerakan tubuh atau bagian tubuh tertentu untuk mewujudkannnya, sedangkan perbuatan pasif adalah tidak berbuat yang seharusnya dokter berbuat. Keharusan berbuat karena kedudukannya, jabatannnya, tugas pekerjaannya, dan lain-lain menyebabkan dokter dalam keadaan tertentu secara hukum diwajibkan untuk berbuat. Karena apabila dokter tidak berbuat sesuai kewajiban hukum yang diembannya, ia bersalah dan dibebani pertanggungjawaban hukum apabila menimbulkan kerugian.

Meskipun demikian dokter adalah manusia biasa, yang dapat melakukan kesalahan dalam menjalankan profesinya, baik yang dilakukan secara sengaja(dolus) maupun tidak sengaja(lalai,culpa) . Sehingga terkadang niat untuk menolong dan menyembuhkan penyakit seorang pasien tidak selalu dapat berhasil dengan baik yang dapat berakibat cacat bahkan kematian pasiennya akibat praktik kedokteran. Bilamana hal tersebut terjadi maka masyarakat yang disebabkan baik dari tingkat kecerdasannya tinggi sehingga bersikap lebih kritis atau karena ketidak tahuannya terhadap pelayanan yang diberikan dokter , pada umumnya terjadi miskonsepsi yang menganggap setiap kegagalan praktek medis tersebut sebagai akibat adanya tindakan dokter yang dapat dikategorikan sebagai malpraktek medis atau akibat kelalaian medis dan akibatnya pasien yang merasa tidak puas dan mengadukan / melaporkan kasus tersebut melalui jalur hukum

Malpraktik / Malpractice berasal dari kata “mal “ yang berarti buruk , sedang kata practice berarti suatu tindakan / praktik, secara harfiah dapat diartikan sebagai suatu tindakan medik "buruk" yang dilakukan oleh dokter dalam hubungannya dengan pasien. (John Healy, 1999 ; 39) Malpraktek sebagaimana definisi yang ada bukanlah suatu rumusan hukum yang diatur dalam undang-undang, melainkan suatu kumpulan dari berbagai perilaku menyimpang yang dapat terjadi karena suatu tindakan yang disengaja (intentional)seperti padamisconduct tertentu, tindakan kelalaian (negligence), ataupun suatu kekurang mahiran / ketidak kompetenan yang tidak beralasan(profesional misconduct). Profesional misconduct ini dilakukan dalam bentuk pelanggaran ketentuan etik, disiplin profesi, hukum administratif (Administrative Malpractice), hukum perdata (Civil Malpractice) dan hukum pidana(Criminal Malpractice)

Malpraktik medik, belakangan ini semakin marak diberitakan dalam mass media, sebagai akibat semakin kritisnya masyarakat terhadap pelayanan medis yang diterimanya menyebabkan semakin mengecilnya kesenjangan pengetahuan antara pasien dan dokter serta makin terbukanya penilaian dan kritik, dengan demikian dokter maupun pasien mempunyai hak dan kewajiban yang dilindungi oleh undang-undang sehingga kedudukannya seimbang. Adanya dugaan terjadinya malpraktek yang tampak kepermukaan selama ini hanyalah pucuk , dari seratus kejadian malpraktik, mungkin cuma sepuluh yang dilaporkan. Kejadian yang terindentifikasi dugaan terjadinya malpraktek medik selama ini tidak semuanya berakhir melalui putusan pengadilan dan bahkan dibiarkan "mengambang“ tanpa ada proses penyelesaian yang baik (Hasbullah 
Thabrany, http:// sorot. Vianews. Com / news/ read/ 34856-tabib pengantar maut)

Meskipun kasus-kasus diatas belum tentu semuanya dapat dianggap sebagai Malpraktek Medik , karena mengingat kesalahan dokter merupakan kesalahan profesi , maka tidaklah mudah bagi siapapun (termasuk penegak hukum) yang tidak memahami profesi ini untuk membuktikannya di pengadilan, meskipun begitu tidak berarti kesalahan dokter tidak mungkin dapat dibuktikan. Pembuktian yang didasarkan atas dipenuhinya tidaknya unsur-unsur tindak pidana tersebut sangat tergantung dari jenis malpraktek yang dituduhkannya. Sehingga dalam hal tuduhan melakukan kealpaan/ kelalaian medik yang mempunyai akibat meninggal , luka berat dan sebagainya , harus dibuktikan adalah adanya unsur perbuatan tercela (salah) yang dilakukan dengan sikap batin berupa alpa atau kurang hati-hati. Sikap batin yang ditujukan pada sifat melawan hukum perbuatan yang akan dilakukan bisa berupa kesengajaan dan juga bisa kelalaian / culpa . Untuk mengukur benar tidaknya perlakuan adalah pada standar profesi dan standar prosedur operasional (Pasal 50 jo 51 UU No. 29 / 2004) dan atau kebiasaan umum yang wajar dalam pelayanan kedokteran, norma hukum, kesusilaan umum.

Dalam aspek hukum pidana , akibat malpraktik kedokteran yang dapat menjadi tindak pidana (Malpraktik Pidana) harus berupa akibat sesuai dengan yang ditentukan dalam UU. Hal ini disebabkan Malpraktik Pidana “ hanya dapat terjadi pada tindak pidana materiil, dimana timbulnya akibat menjadi syarat selesainya tindak pidana itu “(kematian, luka berat, dan lainnya). Beberapa pasal dalam Kitab Undang-Undang Hukum Pidana (KUHP) dapat diterapkan dalam malpratek kedokteran antara lain : (1) Pasal 344 (Euthanasia). Pasal ini melarang segala bentuk pengakhiran hidup manusia walaupun atas permintaannya sendiri (Kematian lihat Pasal 1 PP Nomor 18 / 1981 Tentang Bedah Mayat Klinis dan Bedah Mayat Anatomis), (2) Pasal 345 (Mendorong bunuh diri dng memberikan sarana (3) Pasal 338 (Pembunuhan), (4) Pasal 346348(Aborsi),(5) Pasal 351(Penganiayaan),(6) Pasal 359 (Kealpaan menyebabkan kematian), (7) Pasal 360 (Kealpaan menyebabkan luka/penyakit). Dalam praktik tuntutan pidana terhadap kasus Malpraktik selama ini terjadi, maka ketentuan Pasal 359 dan 360 KUHP yang paling sering didakwakan terhadap kesalahan dokter yang menyebabkan kematian dan / atau luka-luka Ketentuan Pasal 359 KUHP dapat menampung semua perbuatan yang dilakukan yang mengakibatkan kematian, dimana kematian bukanlah dituju atau dikehendaki.

Namun dalam praktik tidaklah mudah untuk membuktikan adanya unsur - unsur kesalahan baik kesengajaan (dolus) maupun kealpaan / kelalaian (Culpa) dalam kasus-kasus yang diindikasikan adanya malpraktik medik , karena sikap batin culpa dalam malpraktik pidana harus berupa culpa lata(gross negligence)yakni suatu bentuk kelalaian berat (yaitu tidak berbuat hati-hati menurut semestinya atau memang sangat hati-hati tetapi perbuatan itu pada prinsipnya tidak boleh dilakukan).Sebagai contoh penerapan unsur-unsur kesalahan karena kelalaian / kealpaan sebagaimana ketentuan Pasal 359 KUHPidana untuk menjerat adanya dugaan Malpraktek Medik tidaklah mudah dilakukan (lihat kasus dr. Setyaningrum), hal ini disebabkan bahwa ada anggapan tidak semua akibat dari tindakan dokter terjadi karena kelalaian dokter, bisa juga diakibatkan adanya resiko tindak medik / resiko medik yang 
harus ditanggung oleh pasien.(Hendrojono Soewono , 2007 ; 125 ) Dalam kasus ini terlihat jelas bahwa ada perbedaan yang cukup signifikan yaitu perbedaan penerapan unsur-unsur kelalaian, yaitu pada tindak pidana biasa (KUHP) yang menjadi fokus adalah akibatnya (gevolg), sedangkan dalam tindak pidana medik yang penting bukan akibatnya tetapi penyebabnya / causanya. Hal ini dipicu juga dengan beragamnya penafsiran dan beragamnya dasar teori dalam memutuskan kejahatan karena kealpaan / culpa , sehingga tidak pula dalam penerapannya hanya mengacu pada salah satu aspek culpa.

Ini berarti dalam pelayanan kesehatan , kesalahan / kelalaian yang timbul dari tindakan dokter lebih cenderung dianggap sebagai “ kelalaian akibat “ , oleh karena itu yang dapat dipidana adalah penyebab dari timbulnya akibat (tindakan dokter yang menyebabkan cacat / matinya pasien). Sehingga dengan demikian untuk menentukan apakah dokter telah melakukan peristiwa pidana sebagai akibat , maka harus terlebih dahulu dicari keadaan/ faktor yang menjadi penyebab terjadinya peristiwa pidana tersebut. Dari uraian tersebut maka unsurunsur kealpaan dalam pelayanan kesehatan mengandung pengertian normatif yang mudah dilihat, artinya perbuatan / tindakan kealpaan itu selalu diukur dengan syarat-syarat bahwa tindakan dokter tersebut setidak-tidaknya sama dengan apa yang diterapkan dilakukan oleh sesama dokter dalam situasi yang sama. Oleh karena itu apapun akibatnya / fatal , namun jika tidak dapat dibuktikan adanya kesalahan / kelalaian/ kealpaan yang berkaitan dengan profesi kedokteran, maka dokter tersebut tidak dapat dituntut di muka sidang.

Disisi lain akibatnya penyimpangan dan atau pelanggaran dari Standar Profesi Medik (SPM) dan Standar Operasional Prosedur (SOP) yang dilakukan oleh dokter dianggap belum tentu merupakan malpraktek medik / malpraktek pidana (criminal maalpractice), karena untuk membuktikan unsur-unsur kelalaian / kealpaan (culpa ) harus memenuhi syarat yaitu : bertentangan dengan hukum , akibatnya dapat dibayangkan , akibatnya dapat dihindarkan , dan perbuatannya dapat dipersalahkan. Dalam praktik timbul permasalahan tentang pengertian kesalahan itu terutama yang menyangkut kesalahan dan atau kelalaian dalam bidang pelayanan kesehatan. Kesulitan yang timbul untuk menentukan adanya kelalaian karena dari semula perbuatan atau akibat yang timbul dalam suatu peristiwa yang tidak dikehendaki ( sikap batin) oleh pembuatnya.Sementara itu sikap batin pada akibat yang merugikan kesehatan / nyawa pasien pada umumnya malpraktek kedokteran tidak dituju / tidak dikehendakinya, walaupun ada kemungkinan kehendak / sikap batin itu memang ditujukan pada akibat buruk pada pasien, misalnya euthanasia ( Pasal 344 KUHP), atau aborsi di luar indikasi medis (Pasal 344, 348 KUHP). Akan tetapi sikap batin yang diarahkan pada perbuatan yang pada umumnya berupa kesengajaan itu , dapat pula merupakan sikap batin pada perbuatan (aktif/pasif) yang dianggap sikap batin kelalaian .Meskipun kesalahan profesional yang dilakukan oleh dokter pada waktu melakukan perawatan dan adanya pihak lain / pasien yang dirugikan atas tindakan dokter dapat dijadikan pegangan pokok untuk menetapkan ada atau tidaknya malpraktek medik , tetapi tidaklah mudah untuk menetapkan waktu / kapan adanya / terjadinya ( unsur kelalaian / kealpaan / kesalahan ) profesional itu. 


\section{B. Pergulatan Penafsiran Hukum Dalam Menentukan Unsur-Unsur Kelalaian Malpraktek Medik (Medical Malpractice)}

Pergulatan penafsiran hukum untuk menentukan unsur- unsur kesalahan / kelalaian dalam Malpraktek Medik sering dijumpai dalam proses penyelesaian suatu tindakan medik yang dilakukan oleh dokter dengan dugaan terjadinya kesalahan/ kealpaan / kelalaian dan penyimpangan prosedur pelayanan kesehatan / kesalahan profesional / kelalaian profesional . Hal ini disebabkan juga adanya masih kaburnya pengertian dan penafsiran masalah malpraktek , sehingga tidak jarang menyebabkan pula kerancuan pemahaman dan pandangan yang mencampur adukkan antara etik profesi dengan norma-norma hukum.

Adanya perbedaan pemahaman dan penafsiran masalah malpraktek dengan menyamakan istilah malpraktek medik (medical malpractice) dengan kelalaian medik (medical negligence) sehingga suatu tindakan medik yang salah dapat disebut sebagai malpraktek sekaligus pelanggaran etik profesi. Di lain sisi ada yang berpendapat bahwa adanya resiko dalam pengobatan (risk of treatment) dan kesalahan penilaian (error of judgement) tidak dapat disebut sebagai malpraktek medik(medical malpraktice) atau kelalaian medik (medical negligence.) Pengertian istilah kelalaian medik yaitu ; “ medical malpractice involves the physician's failure to conform to the standard of care for treatment of the patient's condition, or lack of skill, or negligence in providing care to the patient, which is the direct cause of an injury to the patient”. Lebih jauh dalam World Medical Association dinyatakan bahwa tidak semua kegagalan medis adalah akibat malpraktek medis, karena suatu peristiwa buruk yang tidak dapat diduga sebelumnya (unforeseeable) yang terjadi saat dilakukan tindakan medis yang sesuai standar tetapi mengakibatkan cedera pada pasien '. An injury orcurring in the course of medical treatment which could not be foreseen and was not the result of the lack or knowledge on the part of the treating physician is untoward result, for which the physician sholud not bear any liability" (John Healy , 1999 ; 6)

Meskipun perlu dipahami , bahwa tidak setiap hasil pengobatan yang tidak sesuai dengan harapan pasien merupakan bukti adanya Malpraktek Medik , dan dokter dinyatakan bersalah telah melakukan kelalaian dalam melakukan pengobatan / tindakan medik , mengingat kejadian semacam itu juga dapat merupakan bagian dari resiko yang harus ditanggung oleh pasien dalam tindakan medik (Resiko Medik) Kesalahan diagnosis juga tidak boleh secara otomatis dijadikan ukuran adanya Malpraktek Medik sebab banyak faktor yang mempengaruhi ketepatan diagnosis, yang kadang-kadang sebagian faktor tersebut berada di luar kontrol dokter.

Dalam prakteknya untuk menentukan unsur - unsur kesalahan / kealpaan / kelalaian dugaan terjadinya malpraktek medik tidaklah mudah, sebab sementara itu ajaran hukum atau teori hukum baik mengenai kesalahan maupun mengenai causalitas tampaknya oleh sebagian orang juga beragam dan dalam segi tertentu terkadang sulit dipahami sehingga keadaan itu menyebabkan ketidaksamaan penerapan dalam praktik hukum. Untuk memahami malpraktik kedokteran dari pandangan hukum, pengertian dan isi serta akibat hukum bagi pembuatnya harus memahami isi dan syarat yang secara utuh ada dalam tiga aspek pokok malpratik kedokteran tersebut. Perbuatan dalam pelayanan medis yang dapat menjadi malpraktik kedokteran dapat saja terjadi pada saat 
pemeriksaan, cara pemeriksaan, alat yang dipakai pada pemeriksaan, menarik diagnosis atas fakta hasil pemeriksaan, wujud perlakuan terapi, maupun perlakuan untuk menghindari kerugian dari salah diagnosis dan salah terapi.

Dari terminologi bahasa, kealpaan mengandung arti kekeliruan , yaitu bahwa sikap batin orang yang menimbulkan keadaan yang dilarang itu bukannya menentang larangan, bukan pula menghendaki atau menyetujui timbulnya hal yang dilarang itu , melainkan karena kesalahan, kekeliruannya dalam batin sewaktu berbuat sehingga menimbulkan keadaan yang dilarang itu , karena ia kurang mengindahkan larangan itu , sehingga perbuatan itu telah terjadi kealpaan, lalai atau teledor. Kealpaan mengandung syarat tidak mengadakan penduga-duga / sikap batin sebagaimana yang diharuskan oleh hukum dan tidak mengadakan penghati-hatian sebagaimana yang diharuskan oleh hukum. Yang dimaksudkan dengan tidak menduga-duga dapat terjadi karena ; (1) pelaku berpikir bahwa akibat tidak akan terjadi karena perbuatannya itu , padahal pandangan itu ternyata tidak benar. Dalam hal ini telah terjadi kealpaan yang disadari ( bewuste culpa). Terletak dalam kesalahan pikir / pandangan yang seharusnya tidak dilakukan ; (2) Pelaku delik sama sekali tidak mempunyai pikiran bahwa akibat yang dilarang itu mungkin terjadi karena perbuatannya, termasuk dalam kealpaan yang tidak disadar ( onbewuste culpa), dan tidak mengadakan penduga-duga karena tidak adanya pikiran sama sekali bahwa akan terjadi akibat yang fatal karena perbuatannya itu . Untuk itu faktor-faktor dalam menentukan seseorang dianggap mempunyai kemampuan bertanggung jawab ada / tidaknya menurut hukum antara lain : (1) keadaan batin orang yang melakukan itu , ini berkaitan erat dengan kemampuan bertanggung jawab, artinya keadaan batin orang yang melakukan perbuatan itu (2) Adanya hubungan batin antara pelaku dan perbuatan yang dilakukan, dimaksudkan dengan hubungan itu dapat berupa dolus ( kesengajaan ) atau culpa ( kealpaan), yang merupakan unsur penting dalam menentukan hubungan ini (3) Tidak adanya alasan pemaaf .

Adanya keadaan dan hubungan batin antara pelaku dengan perbuatan yang dilakukan tersebut merupakan unsur-unsur yang dominan dalam mengklasifikasi hubungan causa / akibat dari perbuatan yang dilakukan.Sikap batin dari orang yang melakukan perbuatan yang dilarang undang-undang karena kelalaian bukanlah menentang aturan dan larangan yang ada, dia tidak menghendaki ataupun menyetujui timbulnya hal yang dilarang, tetapi kesalahannya, kekeliruannya ada dalam batinnya sewaktu ia berbuat, sehingga menimbulkan hal-hal yang dilarang. Jadi bukanlah semata-mata menentang larangan tersebut dengan melakukan hal yang dilarang itu, tetapi juga tidak begitu mengindahkan larangan. Ini tercermin dari perbuatannya, orang tersebut lalai dalam melakukan perbuatan tersebut sebab jika ia cukup mengindahkan adanya larangan pada waktu melakukan perbuatan yang secara obyektif menimbulkan hal yang dilarang, ia tentu tidak akan lalai atau kurang berhati-hati, sehingga tidak akan sampai menyebabkan hal yang dilarang itu terjadi. Dalam hal yang demikian maka yang menjadi tolok ukur adalah pikiran dan kemampuan seseorang untuk menentukan, apakah setiap orang yang termasuk dalam kategori yang sama dengannya dan dalam kondisi yang sama serta sarana yang sama akan berbuat lain. Apabila orang lain yang termasuk kategori yang sama akan berbuat yang sama dengan dia dapat dikatakan tidak ada kelalaian atau kealpaan. Namun , 
sebaliknya jika orang lain tersebut akan berbuat lain dengan apa yang dilakukan olehnya dapat dikatakan ia telah berbuat kurang hati-hati , lalai dan alpa.(Adami Chazami , 2007 ; 84 ) . Sikap batin adalah sesuatu yang ada dalam batin sebelum seseorang berbuat, yang dapat berupa kehendak, pengetahuan , pikiran , perasaan yang melukiskan keadaan batin seorang sebelum berbuat. Apabila kemampuan mengarahkan dan mewujudkan alam batin ke dalam perbuatanperbuatan tertentu yang dilarang, maka hal itu disebut “ kesengajaan “. Sebaliknya apabila kemampuan berpikir , perasaan dan kehendak itu tidak digunakan sebagaimana mestinya dalam hal melakukan suatu perbuatan yang pada kenyataannya dilarang , maka sikap batin tersebut dinamakan " kelalaian “ / Culpa “.

Sikap batin dalam ajaran culpa subyektif antara lain: (1) Sikap batin dalam hubungannya dengan wujud dan cara perbuatan adalah sikap batin yang tidak / kurang mengindahkan / kurang hati-hati baik mengenai wujud dan cara perbuatan atau alat yang digunakan dalam perbuatan .; (2) Sikap batin dalam hubungannya dengan sifat hukumnya perbuatan adalah sikap batin yang seharusnya ada pada diri sebelum berbuat, yaitu perbuatan yang hendak dilakukannya adalah terlarang . ; (3) Sikap batin dalam hubungannya dengan obyek perbuatan adalah sikap batin yang tidak mengindahkan sesuatu mengenai obyek yang akan dilakukan perbuatan ( dokter tidak mengindahkan ketahanan tubuh pasien ). (4) Sikap batin dalam hubungannya dengan akibat terlarang dari suatu perbuatan. Sikap batin culpa terjadi apabila dokter tidak menyadari bahwa dari perbuatan yang hendak dilakukannya dapat menimbulkan akibat yang dilarang dalam hukum. Atau akibat itu disadari bisa timbul namun karena berdasarkan pemikiran tentang pengalaman, kepintarannya , kondisi pasien yg prima , yakin akibat tidak akan timbul tetapi ternyata akibat yang dilarang timbul , atau akibat disadari dapat timbul namun diyakini ia memiliki kemampuan untuk menetralisir gejala-gejala menuju akibat sehingga akibat tidak terjadi. (Adami Chazami, 2007 ; 85 )

Lain halnya dengan ajaran culpa obyektif yang menilai sikap batin lalai pada diri seseorang dengan membandingkan antara perbuatan pelaku pada perbuatan yang dilakukan orang lain yang berkualitas sama dalam keadaan yang sama pula. Oleh karena itu sikap batin culpa dalam malpraktek pidana harus berupa culpa lata ( gross negligence, grote onachzaamheid) yakni suatu bentuk kelalaian berat dimana dokter melakukan tindakan ceroboh, yang teledor , sikap batin tidak mau tahu, bahkan mau benar sendiri, tidak ambil pusing terhadap akibat yang akan terjadi, yang harus dipertanggungjawabkan secara hukum

Di dalam ilmu hukum kedokteran , terdapat rumusan tentang kelalaian yang sudah berlaku universal sebagai berikut : “ Kelalaian adalah ketelitian yang wajar , tidak melakukan apa yang seorang lain dengan ketelitian serta kehatihatian akan melakukannya dengan wajar , atau melakukan apa yang seorang lain dengan ketelitian yang wajar justru tidak melakukannya “. Ini berarti bahwa kelalaian mencakup dua hal yaitu karena melakukan sesuatu yang seharusnya tidak dilakukan atau karena tidak melakukan sesuatu yang seharusnya dilakukan, dengan kata lain kealpaan / kelalaian terjadi apabila seorang melakukan perbuatan itu karena ia alpa/lalai terhadap kewajiban yang menurut tatatanan kehidupan masyarakat yang berlaku seharusnya tidak dilakukan olehnya ( J.Guwandi , 2003 ; 15.) . Kelalaian sebagai melakukan tindakan kedokteran di 
bawah standar pelayanan medik . Kelalaian bukan merupakan pelanggaran hukum atau kejahatan jika tidak membawa kerugian atau cendera kepada orang lain dan orang itu dapat menerimanya. Jika kelalaian sampai menimbulkan kerugian materi , mencelakakan dan bahkan merengut nyawa orang lain , maka kelalaian tersebut merupakan kelalaian berat ( culpa lata) dan dapat diklasifikasikan tindak pidana. Kelalaian adalah suatu bentuk dari malpraktek, sekaligus merupakan bentuk malpraktek yang paling sering terjadi. Pada dasarnya kelalaian terjadi apabila seseorang dengan tidak sengaja, melakukan sesuatu yang seharusnya tidak dilakukan atau tidak melakukan sesuatu yang seharusnya dilakukan oleh orang yang memiliki kualifikasi yang sama pada suatu keadaan dan situasi yang sama.( Yusuf Hanafiah , 1999 ; 13 )

\section{Unsur Kelalaian Dalam Malpraktek Medik .}

Dari berbagai kasus Malpraktek Medik yang terjadi di Indonesia, yang banyak mendapat sorotan dan menjadi bahan kajian dari kalangan dokter dan praktisi hukum, dan telah memperoleh keputusan hukum yang pasti (inkracht) adalah kasus dr. Setianingrum (Tahun 1979). Dalam kasus ini ada perbedaan pendapat yang cukup signifikan dalam melakukan penilaian / pertimbangan hukum mengenai unsur- unsur kelalaian . Dalam Putusan Pengadilan Negeri Pati Nomor 8 / 1980/Pid/PN.PT. Tanggal 2-9 Tahun 1981, yang dalam amar putusannya menyatakan bahwa terdakwa (dr. Setianingrum) "bersalah melakukan kejahatan karena kealpaannya menyebabkan orang lain meninggal dunia “ , dan terdakwa dijatuhi hukuman pidana 3 (tiga) bulan dengan masa percobaan selama 10 (sepuluh) bulan. Putusan ini kemudian diperkuat Pengadilan Tinggi Jawa Tengah Nomor 203/1981/Pid/PT Smg tanggal 19 Mei 1982 . Ada dua bagian pertimbangan hukum yang menunjang amar putusan yaitu : (1) bagian pertimbangan adanya kelalaian dokter dan (2) bagian pertimbangan akibat kematian oleh adanya kelalaian dokter (causaal verband).

Mahkamah Agung melalui putusannya Nomor 600/K/1983 tanggal 27 Juni 1984 , yang dalam amar putusannya " membatalkan putusan PT Semarang dan Putusan Pengadilan Negeri Pati dan Menyatakan kesalahan terdakwa yang didakwakan kepada dr. Setianingrum tidak terbukti, dan membebaskan terdakwa dari dakwaan tersebut ". Yang dalam pertimbangan hukumnya pada intinya bahwa " ada atau tidaknya kelalaian bergantung pada apakah dokter telah berusaha secara maksimal untukmenyelamatkan jiwa pasien berdasarkan kemampuan yang sewajarnya yang dimiliki serta alat / sarana yang tersedia padanya “.

Di sisi yang lain dalam pertimbangan hukumnya Mahkamah Agung menyatakan bahwa penerapan Pasal 359 KUHP dalam perkara ini tidak benar , terutama mengenai penafsiran unsur kealpaan (Schuld) dalam pasal tersebut dengan causa dari kematian. Pengertian kealpaan dalam kasus ini harus dikaitkan dengan profesi dokter , sehingga pengertian kealpaan dalam Pasal 359 KUHP mengandung unsur dapat dihindarkan akibat ( vermijnbaarheid), dapat dibayangkan akibat sebelumnya (voorzienbaarheid), dapat di cela si pembuat (verwijtbaarheid).

Bandingkan Putusan Pengadilan Negeri Pati dan Pengadilan Tinggi Semarang dengan Putusan Mahkamah Agung, dimana terdakwa dinyatakan bersalah melakukan kejahatan karena kealpaannya menyebabkan orang lain 
meninggal dunia , dan diputuskan adanya kelalaian dokter dan akibat kematian oleh adanya kelalaian dokter ( sikap batin yang tidak menghendaki kematian (akibat ) tetapi kekeliruannya adalah kurang mengindahkan/ lalai dan tidak menduga-duga. Fokus pertimbangan pada ke dua Pengadilan mengenai Culpoos tersebut tampak jelas pada akibat (kematian ) dan pada sifat melawan hukumnya perbuatan. Culpoos pada akibat tercantum dalam pertimbangan hukum yang menyatakan “ menimbang bahwa syarat tidak mengadakan penduga-duga yang perlu ini diletakkan pada hubungan sikap batin terdakwa dengan akibat yang timbul dari perbuatannya, yaitu kematian. Sehingga membuktikan pada diri terdakwa sebelum berbuat telah terdapat sikap batin culpoos pada akibat. Sedangkan Culpoos pada sifat melawan hukumnya perbuatan ," menimbang kurang hati-hatinya terdakwa ternyata bahwa sebelumnya untuk keamanan penyuntikan ia tidak meneliti dengan menanyakan riwayat sakitnya pasien yang berhubungan dengan alergi melainkan hanya percaya saja kata pasien yang berpendidikan rendah dan awam obat-obatan ". Dalam peristiwa ini seharusnya fokus pertimbangan hukum adanya culpoos ialah pada akibat dari pemberian suntikan / obat , bukan pada penghindaran akibat setelah suntikan / obat yang diberikan.Oleh karena fokus / obyek pertimbangan mengenai Culpoos terhadap akibat adalah pada perbuatan memberikan pada tindakan yang pertama ( memberikan suntikan ), bukan pada perbuatan menghilangkan gejala menuju kematian , sehingga bentuk sikap batin culposs terhadap akibat dilakukan sebelum perbuatan itu dilakukan , bukan sesudah perbuatan itu dilakukan.

Akan tetapi dalam putusan Mahkamah Agung tersirat bahwa setiap tindakan medik ada kemungkinan terjadinya resiko yang dapat membahayakan pasien dengan alasan bahwa dokter sudah mengupayakan secara sungguhsungguh dan hati-hati untuk kesembuhan pasien, sebagaimana layaknya praktek rata-rata dokter dalam kondisi dan kemampuan serta lingkungan yang sama. (Hermin Hadiati Koeswadji , 1998 ; 117 - 118 ). Dari putusan pengadilan tersebut, telah terjadi pergeseran paradigma bukan saja pada ajaran culpa subyektif dan culpa obyektif dalam perbuatan yang termasuk dalam Malpraktek atau Resiko Medik , tetapi juga telah terjadi pergulatan untuk menentukan ada / tidaknya unsur-unsur kelalaian dalam tindakan medik yang diambil oleh seorang dokter. Pada Putusan MA Nomor 600 /K/Pid/1983, terjadi pergeseran dari titik pertimbangan hukum ialah kesalahan / kelalaian terhadap akibat sebelum dan pada saat tindakan dokter . Dimana Putusan MA tentang “ kesalahan / kelalaian adalah pada penghindaran akibat kematian yang sudah tampak gejalanya setelah perbuatan dilakukan oleh dokter , bukan kelalaian pada akibat perbuatan dokter. Dari Putusan MA dapat disimpulkan bahwa MA menggunakan ajaran culpa obyektif yaitu dengan memperimbangkan dokter yang baru berpengalaman kerja selama 4 tahun , bekerja di Puskesmas yang terbatas sarananya .

Pertimbangan MA tentang syarat “ kelalaian “ pada apakah dokter telah berusaha secara maksimal untuk menyelamatkan jiwa pasien berdasarkan kemampuan sewajarnya yang dimiliki serta alat / sarana yang tersedia padanyadan sesuai dengan standar profesi medik ( SPM) dan standar operasional prosedur ( SOP ) . Sehingga terlihat bahwa unsur kelalaian dalam kasus ini bergeser dari “ akibat “ perbuatan memberikan pengobatan menjadi perbuatan menghilangkan gejala setelah melakukan perbuatan., padahal sikap "batin culpoos " terbentuk dari akibat dilakukannya suatu perbuatan , dan bukan 
sesudahnya perbuatan itu dilakukan. Sebenarnya ukuran ada atau tidaknya sikap batin culpoos terhadap akibat yang bertumpu pada apakah dokter telah berusaha secara maksimal berdasarkan kemampuannya yang sewajarnya yang dimiliki serta alat / sarana yang tersedia padanya “ tidak dapat digunaan sebagai bahan pertimbangan hukum tentang adanya sikap batin culpos terhadap akibat kematian yang telah diperbuatnya “ .

Menurut Penulis, putusan Mahkamah Agung dalam pertimbangan hukum tentang culpoos tersebut kurang tepat , karena seharusnya pertimbangan hukum tentang culpoos terhadap akibat adalah perbuatan yang dilakukan sebelum dan pada saat melakukan perbuatan itu , bukan pada setelah perbuatan itu dilakukan. Pertimbangan hukum Mahkamah Agung tersebut lebih tepat sebagai pertimbangan untuk faktor- faktor yang meringankan bagi perbuatan itu, bukan sebagai pertimbangan ada atau tidaknya culpoos terhadap akibat kematian seseorang. Oleh karena itu dalam disimpulkan untuk bekerjanya hukum pidana dalam kasus malpraktek medik, maka unsur negligence merupakan dasar teoritika pertanggungjawaban pidana, negligence harus dicontohkan sebagai conduct which fails below the standard established by law for the protection of others against in reasonable rish of harm. Jadi menurut hukum pidana (menggunakan pasal manapun) adanya kesalahan / kelalaian dalam pelayanan kesehatan harus dapat dibuktikan unsur-unsur :

(1) Duty of Care : Seorang dokter berkewajiban memberikan pelayanan yang profesional (with reasonable care and skill) kepada pasien. Kewajiban ini sudah dengan serta merta terjadi begitu seorang dokter memberikan indikasi ia bersedia memeriksa dan melayani pasien. Duty of care merupakan kontrak sosial dari dokter kepada pasien, yang landasannya adalah kausalitas, walaupun demikian kontrak sosial dokter bisa dilihat manakala ia mengucapkan sumpah dokter.Untuk menentukan apakah prinsip duty of care ini diperhatikan oleh dokter atau tidak bisa diukur dengan mengacu kepada culpa lata.

(2) Breach of Duty: Unsur ini adalah bahwa seorang dokter melakukan baik culpa lata maupun culpa levis terhadap standar-standar pelayanan yang harus dilakukan.

(3) Adanya harm dan damages ; Untuk menentukan unsur ini maka perlu dibuktikan hubungan kausalitas baik yang merupakan cause in fact maupunproximate cause. Unsur ini penting dibuktikan untuk menentukan sifat melawan hukum terhadap perbuatan sebagai salah satu unsur dari suatu tindak pidana. Para penegak hukum harus bisa membuktikan ada hubungan kausalitas antara kelalaian dokter atau unprofessional conduct dengan kerugian yang ditimbulkan oleh perbuatan dokter atau institusi kepada pasien. Perlu kehatihatian dari penegak hukum untuk menentukan malpraktek tersebut, sebab bisa saja perbuatan dokter merupakan hasil akhir yang buruk dalam tindakan medis. Jadi kerugian yang sudah dapat diramalkan, bukan akibat kurangnya kemampuan atau ketrampilan dokter.

Parameter untuk menilai adanya dugaan pelanggaran hukum (pidana) apabila telah memenuhi parameter sebagai voorportal atau gerbang terdepan yang ketat dan limitatif sifatnya ( Indriyanto Seno Adji , 2005 ; 3 ) , adalah sebagai berikut: 
(1) Adanya zorgvuldigheid (kecermatan), artinya seorang dokter memiliki kemampuan yang normal, suatu zorgvuldigheid yang biasa, dengan hubungan yang wajar dalam tujuan merawat (pasien);

(2) Adanya diagnosis atau terapi, artinya perbuatan-perbuatan ini dilakukan oleh dokter yang sangat tergantung dari pengetahuan yang ia miliki, kemampuan yang wajar dan pengalaman yang ada. Apabila diagnosis banyak dipengaruhi oleh posisi, perkembangan dan keadaan dari ilmu kedokteran itu sendiri, maka terapi dapat dipengaruhi oleh posisi perkembangan dan keadaan dari ilmu kedokteran itu sendiri, maka terapi dapat dipengaruhi oleh beberapa faktor seperti keadaan psikhis, psikologis, dan kompilasi yang timbul tanpa dapat diperhitungkan lebih dahulu ;

(3) Standar profesi, berupa : (a) Kemampuan yang average (rata-rata), (b) Category and Condition equel (kategori dan keadaan yang sama) ,(c) Adanya pemenuhan asas proposionalitas dan subsidaritas dalam tujuan melakukan tindakan kedokteran/medis.

Semua parameter atau karakteristik tersebut menurut Joseph H. King Jr. seperti dikutip Indriyanto Seno Adji, merupakan Professional Competency of Experts dan Geographic Competency of Experts. Oleh karena itu apabila terjadi kegagalan atau bahkan kematian terhadap pasien akibat pelayanan medis yang dilakukan dokter, harus dapat dibuktikan dulu adanya suatu hubungan kausalitas atau sebab akibat antara tindakan medis dokter dengan cedera atau matinya pasien. Biasanya dibedakan antara cause in fact dengan proximate cause. Yang pertama dipermasalahkan adalah, perbuatan dokter yang mengakibatkan kerugian (mati/luka) pada pasien secara faktual. Yang kedua mempermasalahkan batas-batas ruang lingkup tanggung jawab dokter yang dihubungkan dengan akibat-akibat perbuatannya. Pengecualian penjatuhan pidana dapat berupa alasan penghapusan pidana tersebut dikenal dengan sebutan alasan pembenar (fait justificatief) dan alasan pemaaf (fait d'excuse).

Selain itu ada pula hal - hal yang dapat membebaskan dokter dari tuntutan malpraktek medik sebagai suatu bentuk kealpaan / kelalaian dalam melaksanakan pengobatan antara lain : 1) Dokter telah melakukan sesuai dengan stadar profesi, standar pelayanan medis dan standar operasional prosedur ; (2) Informed concent, dimana persetujuan pasien / keluarganya merupakan pelaksanaan hak dasar pasien (the right to health care) dan hak untuk menentukan nasib sendiri (the right of self determination) ; (3) Contribution Negligence, yaitu pasien turut bersalah dalam pengobatan / perawatan terhadap dirinya sendiri ; (4) Respectable Minority dan Error of Judgment ,kekeliruan pilihan dokter yang tidak dapat dipertanggungjawabkan kepada dokter karena tidak ada kelalaian dalam pilihan itu; (5) Volenti Non Fit Iniura atau Asumption of Risk yaitu asumsi yang sudah diketahui sebelumnya tentang adanya resiko medis yang tinggi pada pasien apabila dilakukan tindakan medis padanya ; (6) Respondeat Superior Vicarious Liability , dokter yang bekerja penuh di Rumah Sakit tidak dapat dipertanggungjawabkan mutlak , tetapi Rumah Sakit ikut bertanggungjawab ; (7) Res Ipsa Loquitur , dalam doktrin ini dibedakan antara Medical Error , yaitu dokter telah melakukan tindakan prosedur / kebiasaan di rumah sakit , dengan Medical Violence, dimana dokter melakukan tindakan medik tidak sesuai dengan prosedur yang benar (malpraktek) . 


\section{Simpulan}

Pergulatan hukum untuk menentukan unsur-unsur kelalaian dalam Malpraktik Medik (Medical Malpractice) adalah terletak pada adanya perbedaan penafsiran dan penerapan antara tindak pidana biasa yang diatur dalam KUHP dan tindak pidana medis . Dimana tindak pidana biasa yang terutama berfokus pada faktor " akibatnya " dari suatu peristiwa pidana, sedangkan dalam tindak pidana medis yang dilihat bukan akibatnya tetapi faktor " penyebabnya “ , sehingga meskipun berakibat fatal tetapi jika tidak ada unsur kelalaian atau kesalahan , maka dokter tidak dapat dipersalahkan. Padahal dari sudut hukum pidana ( KUHP) penilaian sifat melawan hukumnya perbuatan dalam culpa lata medis harus dimulai dari akibat kematian / luka , baru kemudian menilai pada tingkah laku medis dalam mengobservasi yang patut disalahkan atau tidak disalahkan. Hal ini menunjukkan dengan adanya pergeseran paradigma yaitu dari "akibat" perbuatan memberikan pengobatan menjadi perbuatan menghilangkan gejala setelah melakukan perbuatan, padahal sikap “ batin culpoos “ terbentuk dari akibat dilakukannya suatu perbuatan , dan bukan sesudahnya perbuatan itu dilakukan. Sebenarnya ukuran ada atau tidaknya sikap batin culpoos terhadap akibat yang bertumpu pada apakah dokter telah berusaha secara maksimal berdasarkan kemampuannya yang sewajarnya yang dimiliki serta alat / sarana yang tersedia padanya " tidak dapat digunaan sebagai bahan pertimbangan hukum tentang adanya sikap batin culpos terhadap akibat kematian yang telah diperbuatnya "Seharusnya culpoos terhadap akibat adalah perbuatan yang dilakukan sebelum dan pada saat melakukan perbuatan itu , bukan pada setelah perbuatan itu dilakukan. Belum lagi sering terjadi pula adanya pergeseran pula mengenai ajaran mengenai culpa subyektif menjadi culpa yang obyektif, yaitu kelalaian yang disadari (bewuste culpoos ) dimana bentuk sikap batin yang menyadari akibat yang terjadi , tetapi di percaya akibat tidak akan terjadi maupun gejala akibat akan terjadi diyakini akibat itu dapat ditiadakan dengan upaya-upaya tertentu yang telah dikuasainya. Hal ini tidak harus demikian karena secara logika dokter harus menyadari tentang pengalamannya berpraktik (belum lama) dan alat yang ada padanya ( serba terbatas) , maka sewajarnya diperlukan kehati- hatian yang lebih tinggi agar tidak melakukan perbuatan yang beresiko dimana akibatnya tidak dapat ditanggulangi. Kelalaian dalam pelayanan kesehatan adalah salah satu bentuk dari malpraktek , yang pada dasarnya terjadi apabila seorang dokter dengan tidak sengaja melakukan tindakan yang seharusnya tidak melakukan yang seharusnya dilakukan oleh dokter lain yang memiliki kualifikasi yang sama pada suatu keadaan dan situasi yang sama. Unsur kelalaian ini terpenuhi apabila dilakukan dokter yang dapat dipertanggungjawabkan (profesi) , bertindak hati-hati dan telah mengakibatkan kerugian / cedera bagi pasien. Kelalaian dokter dapat berbentuk "Malfeasance" yaitu melakukan tindakan yang melanggar hukum / membuat kebijakan / keputusan yang tidak tepat ( melakukan tindakan tanpa indikasi yang memadai) ;"Misfeasance" , yaitu melakukan pilihan keputusan/tindak medis yang tepat tetapi melaksanakannya dengan tidak tepat ( melakukan tindakan medis dengan menyalahi prosedur) ; “ Nonfeasance " yaitu tidak melakukan tidakan medis yang merupakan kewajiban bagi dokter. 
Hasil akhir suatu pengobatan sangat tergantung pada banyak faktor , sehingga tindakan medik yang dilakukan oleh dokter antara lain dapat merupakan akibat dari : (a) Perjalanan dan komplikasi dari penyakitnya sendiri (Cilinical course of the disease); (b) Resiko Medis (Medical risk) ;(c) Resiko tindakan operatif (Surgical risk) ; (e) Efek samping pengobatan dan tindakan (Adverse Effect or reaction); (f) Akibat keterbatasan fasilitas (Limitation of resources) ; (g) Kecelakaan medik ( Medical accident) ; (h) Ketidaktepatan dignoses (Error of judgement) ; (i) Kelalaian medik (Medical negligence); (j) Malpraktik medik (Medical malpractice). Tindakan yang dilakukan oleh dokter yang memenuhi unsur-unsur kesalahan (materiil ) dalam KUHP , tidak selalu dapat dinyatakan bersalah dan dijatuhi pidana , misalnya dalam pembedahan yang melukai orang dengan pisau, meskipun memenuhi unsur-unsur "penganiayaan" tetapi tindakan dokter terebut bukan merupakan suatu tindak pidana. Suatu tindakan medik secara materiil tidak bertentangan dengan hukum apabila memenuhi persyaratan antara lain ; (1) tindakan itu mempunyai indikasi / petunjuk medik berdasarkan pada tujuan tindakan medik ;(2) tindakan dilakukan sesuai dengan ketentuan terapi pengobatan ; (3) tindakan itu dilakukan dengan persetujuan / izin yang bersangkutan (informed consent).Bersalahnya atau tidaknya dokter ternyata diukur dari apakah tindakan medik itu telah memenuhi standar pelayanan medik / standar profesi medik dan apakah adanya contribution negligence dari pasien, apakah kemampuan dokter tersebut telah memenuhi kemampuan kemampuan rata-rata pada umumnya dan apakah tindakandokter tidak melanggar kode etik kedokteran. Sehingga apabila semua prosedur tersebut telah dilaksanakan dengan baik , maka kegagalan dokter dalam melakukan tindakan medik tidak dapat dikategorikan sebagai criminal malpractice / malpraktek pidana tetapi harus dikategorikan sebagai resiko medik.

Dokter dapat dianggap melakukan suatu kelalaian medik, apabila memenuhi unsur-unsur ; (a). Duty ( kewajiban ) untuk melakukan suatu tindakan / tidak melakukan tindakan tertentu terhadap pasien pada situasi dan kondisi tertentu ; (b)Dereliction of the duty, penyimpangan kewajiban ; (c) Damage (kerugian), semua yang dirasakan pasien sebagai kerugian akibat pelayanan dokter; (d)Direct causal relationship , hubungan sebab akibat yang nyata , terdapat hubungan sebab akibat antara penyimpangan kewajiban dengan kerugian yang timbul. Oleh karena itu dalam mengadili perkara malpraktek perlu ada kesamaan pandangan, bahwa penentuan kesalahan dari dokter tidak bisa secara serta merta dilihat dari aspek hukum, tetapi harus menyertakan pendapat atau putusan peradilan disiplin medik . Hasil peradilan disiplin medik bisa merupakan atau bermakna sebagai kesaksian ahli, terbukti tidaknya seorang dokter telah melakukan kejahatan medik sebenarnya dapat menggantungkan dari pada putusan peradilan disiplin profesi dokter. Dalam peradilan pidana misalnya unsur sifat melawan hukum yang harus dibuktikan secara formil dan materiil, dapat diperkuat atau diperlemah oleh apakah suatu perbuatan juga melanggar peraturan disiplin atau etik sekaligus atau tidak. Dalam rangka penegakan hukum terhadap malpraktek medik, memang harus dilakukan secara sangat hati-hati karena disatu sisi tipisnya perbedaan antara pelanggaran administrasi dan pelanggaran pidana, tipisnya perbedaan antara kesalahan medik dan resiko medik , disisi yang lain perlu diperhatikan adalah kepentingan pasien korban 
malpraktek medik . Perlu dibuatkan landasan hukum khusus mengenai malpraktek medik , baik mengenai bentuk , jenis, klasifikasi perbuatan yang termasuk malpraktek medik, maupun prosedur penyelesaian baik secara non litigasi maupun litigasi. Hal ni sangat diperlukan untuk dijadikan pedoman dan petunjuk bagi pasien yang mengalami dugaan terjadinya malpraktek medik.

\section{DAFTAR PUSTAKA}

Adami Chazami, 2007, Malpraktek Kedokteran, PT. Bayumedia Publising, Malang.

Azwar , 2002 , Sang Dokter , Mega Point , Bekasi

Guwandi , 2005 , Medical Error dan Hukum Medis , Balai Penerbit Fakultas Kedokteran Universitas Indonesia , Jakarta.

Hendrojono Soewono , 2007 , Batas Pertanggungjawaban Hukum Malpraktek Dokter Dalam Transaksi Terapeutik, Srikandi , Surabaya.

Hermin Hadiati Koeswadji ,1998 , Hukum Kedokteran, Citra Aditya Bakti , Bandung

Indriyanto Seno Adji, 18 Juni 2005, Malpraktek Medis : Standar Profesi dan Pertanggungjawaban Pidana, Makalah.

J.Guwandi , 2003 , Misdiagnosis atau Malpraktek Jurnal Perhimpunan Rumah Sakit Seluruh Indonesia, Volume 3 ,

John Healy , 1999 , Medical Negligence : Common Law Perspectives , Sweet \& Maxwell , London

Jusuf Hanafiah dan Amri Amir, 1999, Etika Kedokteran dan Hukum Kesehatan, Buku Kedokteran EGC.

Veronika Kumalawati, 2002, Hukum dan Etika Dalam Praktik Dokter, Pustaka Sinar Harapan, Jakarta.

WJS Poerwadarminta, 1976, Kamus Umum Bahasa Indonesia, Balai Pustaka. 